\title{
MENINGKATKAN DISIPLIN ANAK KELOMPOK B MELALUI PERMAINAN TRADISIONAL UMPET BATU
}

\author{
Siti Rahmah ${ }^{1}$; Zirmansyah ${ }^{1}$ \\ ${ }^{1}$ Program Studi Pendidikan Guru Pendidikan Anak Usia Dini, Fakultas Psikologi dan Pendidikan, \\ Universitas Al-Azhar Indonesia, Jalan Sisingamangaraja, Kebayoran Baru, Jakarta Selatan 12110 \\ Penuli untuk Korespondensi/ E-mail: zirmansyah@uai.ac.id
}

\begin{abstract}
Abstrak - Disiplin dapat mengasah perkembangan sosial emosional pada anak. Penelitian ini bertujuan untuk meningkatkan disiplin melalui permainan tradisional pada anak kelompok B. Penelitian ini berupa Penelitian Tindakan Kelas menggunakan model Kemmis dan Mc.Taggart. Subjek penelitian adalah Kelompok B1 yang berjumlah 24 orang anak di TK Al Kautsar. Data diambil melalui observasi dan dokumentasi dalam pengumpulan data. Teknik analisis data menggunakan teknik data kualitatif dan kuantitatif. Penelitian ini dikatakan berhasil jika $75 \%$ anak berhasil mencapai dua butir indikator. Hasil penelitian menunjukkan bahwa disiplin anak kelompok B1 meningkat. Hal tersebut dapat dilihat dari nilai rata-rata anak yang mendapat skor 3 pada setiap indikator per siklus dari siklus I ke siklus II pada indikator taat pada aturan permainan siklus I sebesar $31.8 \%$ dan siklus II sebesar $77.2 \%$, artinya terdapat peningkatan sebesar $45.4 \%$. Pada indikator mengatur diri sendiri siklus I sebesar $31.8 \%$ dan siklus II sebesar $77.2 \%$, artinya terdapat peningkatan sebesar 45.4\%. Kesimpulannya adalah permainan tradisional dapat meningkatkan disiplin pada anak kelompok B di TK Al Kautsar Pondok Bambu Jakarta Timur.
\end{abstract}

Kata kunci: Disiplin, Permainan, Tradisional

Abstract - Discipline can hone social emotional development in children. The aims of the study is to improve discipline through traditional games in children in group B.This research is a Class Action Research using the Kemmis and Mc.Taggart models. The subject of this study was Group B1, with 24 children in Al Kautsar Kindergarten. Data is taken through observation and documentation in data collection. To analyze the data,the writer use qualitative and quantitative data techniques. This research is said to be successful if $75 \%$ of children reach two indicators of success. The results shows that child discipline in group $B 1$ increased. This can be seen from the results of the average increase in scores of children who got a score of 3 on each indicator per cycle from cycle I to cycle II on the indicators of obeying the game rules for the first cycle of $31.8 \%$ and the second cycle of $77.2 \%$. it means there is an increase of 45.4\%. On the indicator self-regulating cycle I is $31.8 \%$ and cycle II is $77.2 \%$, it means there is an increase of $45.4 \%$.It can be concluded that through playing traditional games can increase children's discipline in group B in Al Kautsar Kindergarten Pondok Bambu East Jakarta.

Keywords: Discipline, Traditional, Games 


\section{PENDAHULUAN}

$\mathrm{U}$ sia dini merupakan usia awal yang paling penting dan mendasar sepanjang pertumbuhan dan perkembangan kehidupan manusia. Memberikan pendidikan pada usia ini sangat penting untuk perkembangan dan kemampuan anak. Pendidikan anak usia dini (PAUD) adalah masa dimana anak belum memasuki pendidikan formal.

Pentingnya PAUD telah dijelaskan dalam Undang-undang No. 20 Tahun 2003 pasal 1 ayat 14, tentang sistem pendidikan nasional yang menyebutkan bahwa pendidikan anak usia dini adalah suatu upaya pembinaan yang ditujukan kepada anak sejak lahir sampai dengan usia enam tahun yang dilakukan melalui pemberian rangsangan pendidikan untuk membantu pertumbuhan dan perkembangan jasmani dan rohani agar anak memiliki kesiapan dalam memasuki pendidikan lebih lanjut. Oleh sebab itu dalam memberikan rangsangan pendidikan dan membantu tumbuh kembang seorang anak perlu dibangun suatu lembaga pendidikan yang diatur oleh Undang-undang Sisdiknas tahun 2003 pasal 1 ayat 14, upaya pembinaan yang ditujukan bagi anak usia 0-6 tahun tersebut dilakukan melalui PAUD. Pendidikan anak usia dini dapat dilaksanakan melalui pendidikan formal dan nonformal, pendidikan anak usia dini jalur formal seperti Taman Kanak-kanak (TK) dan Raudatul Athfal (RA) dan bentuk lain yang sederajat. Pendidikan anak usia dini jalur nonformal berbentuk Kelompok Bermain (KB), dan Taman Penitipan Anak (TPA).

PAUD terutama pendidikan di Taman Kanakkanak (TK) yang berkaitan dengan pendidikan sikap terletak pada perkembangan nilai kecerdasan sosial-emosional. Spesifikasi perkembangan kecerdasan sosial emosional yang menyebutkan bahwa tingkat pencapaian perkembangan sosial emosional anak adalah mengenal tata krama dan sopan santun sesuai dengan nilai sosial budaya setempat, memahami peraturan dan disiplin serta menunjukan rasa empati (Permendikbud, 2014: 146). Dari pernyataan di atas salah satu yang harus ditingkatkan oleh guru kepada anak adalah disiplin.

\section{Disiplin}

Hidayati menyatakan (2016: 156) disiplin sebagai sikap ketaatan dan kepatuhan terhadap peraturan dan norma yang berlaku di kehidupan sehari-hari. Disiplin merupakan kunci keberhasilan dalam aktivitas peserta didik. Kegiatan disiplin mengandung makna menghargai waktu untuk seluruh aktivitas yang dilakukan. Sedangkan menurut Schaefer dalam Aulina (2013: 38), disiplin mencakup pengajaran, bimbingan atau dorongan yang dilakukan oleh orang dewasa yang bertujuan untuk menolong anak belajar dalam hidup sebagai makhluk sosial dan untuk mencapai pertumbuhan serta perkembangan mereka yang optimal. Maksud dari kalimat bimbingan atau dorongan disini adalah guru membantu dalam membimbing serta mengarahkan anak ke arah yang lebih baik untuk kehidupan dimasa mendatang sehingga disiplin sangat penting di ajarkan kepada anak sejak dini. Berdasarkan pendapat beberapa ahli di atas, maka dapat disimpulkan bahwa kedisiplinan anakusiadini pada dasarnya adalah sikap taat dan patuh terhadap aturan yang berlaku, yang di dalamnya terdapat pengajaran, bimbingan atau dorongan yang dilakukan oleh orang dewasa kepada anak usia dini yang tidak lepas dari nilai moral, dan kebiasaan-kebiasaan baik di rumah, sekolah, maupun di lingkungan masyarakat yang dilakukan oleh anak usia dini (0-6 tahun) agar anak tumbuh dengan memiliki perilaku yang baik.

Menurut Semiawan (2006: 93) disiplin dapat terbagi dalam tiga macam yaitu:

1. Disiplin dalam waktu

Kedisiplinan dalam hal ini berarti siswa harus belajar untuk terbiasa mengatur waktu dalam kehidupan sehari-hari bisa bermula dari perbuatan kecil. Seperti datang tepat waktu ke sekolah, tidak membolos dan lain-lain.

2. Disiplin dalam belajar

Siswa yang mempunyai kedisiplinan dalam belajar adalah siswa yang mempunyai jadwal serta motivasi belajar di sekolah dan di rumah. Seperti dalam mengerjakan tugas dari guru.

3. Disiplin dalam bertata karma

Adapun yang dimaksud dengan disiplin bertata karma adalah kedisiplinan yang berkaitan dengan sopan santun, akhlak atau 
etika siswa baik kepada guru, teman dan lingkungan.

Dari penjelasan macam-macam disiplin di atas dapat disimpulkan bahwa disiplin di sekolah sangat penting dan memiliki pengaruh dalam menghadapi masalah di kehidupan sehari-hari, baik di kehidupan pribadi maupun di kehidupan bermasyarakat.

Faktor yang mempengaruhi disiplin adalah konsisten, dimana konsistensi itu sangat diperlukan ketika peraturan dibuat seharusnya dapat ditegakkan hal ini dapat dijadikan acuan dalam mendisiplinkan anak usia dini. Selain itu faktor internal dan eksternal juga sangat berpengaruh dalam menumbuhkan kedisiplinan anak. Disiplin adalah kesediaan anak untuk mentaati ketentuan atau aturan yang berlaku. Ketaatan bukan Karena paksaan, tetapi atas dasar kesadaran tentang nilai dan pentingnya mentaati peraturan sehingga dapat membentuk perilaku yang baik (Sabri, 2005: 54). Dengan kata lain kedisiplinan yang dilakukan sejak dini dapat memberikan dampak yang baik bagi kehidupan anak selanjutnya, karena disiplin diri merupakan salah satu faktor kesuksesan seseorang dimana anak dapat mengatur waktunya dengan baik.

Kesadaran untuk memiliki sikap disiplin pada anak tidak dapat terbentuk begitu saja tanpa adanya bimbingan dan dorongan dari orang dewasa. Disiplin yang baik tumbuh dari dalam diri anak sebagai unsur kebiasaan tanpa adanya paksaan. Sehubungan dengan hal ini guru memiliki peran yang sangat besar dalam meningkatkan disiplin pada anak di sekolah karena guru sebagai pendidik yang terlibat langsung dalam meningkatkan kedisiplinan anak.

Disiplin dalam Permendikbud No. 137 Tahun 2014 dituliskan bahwa disiplin pada anak usia 5-6 tahun berdasarkan tingkat pencapaian perkembangannya sebagai berikut: anak tahu akan haknya, mentaati aturan kelas (kegiatan, aturan), mengatur diri sendiri, serta bertanggungjawab atas perilakunya untuk kebaikan diri sendiri. Dari pernyataan di atas disiplin pada anak usia 5-6 tahun seharusnya sudah dapat tertib dan terarah seperti anak mampu berbaris dengan rapi pada saat mengantri untuk cuci tangan, mau berbagi dan bergantian pada saat bermain, mampu memperhatikan dan mendengarkan guru pada saat apersepsi dengan baik tanpa mengobrol dengan temannya, datang tepat waktu ke sekolah, serta tidak berbohong.

Spock dalam Mufidah (2012: 2) mengemukakan konsep positif dari disiplin ialah sama dengan pendidikan dan bimbingan karena menekankan pertumbuhan di dalam disiplin dan pengendalian diri kemudian akan melahirkan motivasi dari dalam diri. Sejalan dengan hal tersebut Suyanto dalam Khasana (2017: 2) mengemukakan bahwa bimbingan serta aturan-aturan sekolah di dalam kelas harus dapat membentuk perilaku anak khususnya dalam disiplin. Disiplin dapat dibiasakan atau ditanamkan dengan cara bermain. Melalui bermain anak dapat memperoleh kesempatan untuk bereksplorasi, bermain dapat membantu memahami konsep sesuai dengan perkembangannya, dan dapat menciptakan rasa senang.

Akan tetapi kenyataannya, disiplin anak usia dini di salah satu TK di Jakarta Timur masih belum optimal. Hal ini terlihat dari hasil observasi awal, ditemukan beberapa anak yang sering melakukan tindakan tidak disiplin. Seperti dari 24 orang anak hanya 10 anak yang mampu berbaris rapi saat mengantri cuci tangan, padalah guru sudah memerintahkan anak agar dapat berbaris dengan rapi. Kemudian pada saat bermain anak yang mau bergantian alat main dengan temannya hanya 12 orang anak dari 24 orang anak, pada saat guru melakukan apersepsi hanya 10 orang anak dari 24 orang anak yang mampu mendengarkan dengan baik tanpa mengobrol. Dimana ketidakdisiplinan anak tersebut belum sesuai dengan tingkat pencapaian perkembangan anak yang tertera di dalam kurikulum.

Terdapat beberapa hal yang menyebabkan terjadinya anak tidak disiplin, yaitu kurangnya bimbingan serta penggunaan metode yang tepat. Guru hanya menggunakan metode ceramah saja. Hal ini terlihat saat observasi guru hanya memberitahu bahwa mendorong dan menyelak teman yang berada di depannya saat sedang berbaris cuci tangan itu tidak baik, guru hanya memberikan penjelasan tanpa memberikan contoh kepada anak cara berbaris dalam mengantri yang benar. Menanamkan disiplin pada anak guru dapat menggunakan metode lain seperti menggunakan metode bermain. Dengan 
bermain anak dapat menumbuhkan sikap taat dan patuh tanpa adanya tekanan karena dilakukan dengan cara yang menyenangkan.

Berdasarkan hal tersebut, bermain dapat digunakan sebagai kegiatan pembelajaran, pelaksanaannya dilakukan secara terstruktur, melihat perkembangan anak didik, alat bermain yang digunakan, waktu, tempat, dan tema permainan. Selain itu bermain dapat mengembangkan potensi anak dan memudahkan guru dalam pencapaian pembelajaran.

Dalam hal ini permainan tradisional yang akan digunakan adalah permainan tradisional umpet batu. Karena dalam permainan tradisional umpet batu guru dapat membuat aturan di setiap langkah-langkah permainannya dari awal hingga akhir, dibandingkan permainan tradisional lainnya seperti petak jongkok, ular tangga, batu tujuh, kakakmia, dan lainnya. Selain itu guru juga dapat mengenalkan kembali kepada anak permainan pada zaman dahulu yang banyak memiliki manfaat dalam menumbuhkan perilaku disiplin bagi aspek perkembangan anak dan tidak kalah menyenangkan dibandingkan permainan zaman sekarang yaitu games online.

\section{Permainan Tradisional Umpet Batu}

Menurut Barbour, dkk (dalam Mulyani, 2016: 24) bermain adalah suatu kegiatan yang dilakukan dengan atau tanpa mempergunakan alat yang menghasilkan pengertian atau memberikan informasi, memberi kesenangan maupun mengembangkan imajinasi pada anak. Kalimat tersebut menunjukkan bahwa bermain dapat dilakukan dengan cara mudah, untuk memperoleh kesenangan dan dapat menambah imajinasi pada anak. Sedangkan Piaget (dalam Kertamuda, 2015: 72) menyatakan bahwa bermain kegiatan yang dilakukan berulangulang dan menimbulkan kesenangan dan kepuasan bagi diri seseorang.

Menurut Piaget, dkk (dalam Musfiroh 2008: 1.24) tahapan bermain pada anak usia dini, sebagai berikut:

1. Bermain Fungsional (Fungsional Play)

Bermain seperti ini berupa gerakan pengulangan yang bersifat sederhana Contohnya: berlari-lari, mendorong dan menarik mobil-mobilan.
2. Bermain Membangun (Constructive Play) Kegiatan bermain ini untuk membentuk sesuatu, menciptakan bangunan dengan alat permainan yang tersedia. Contohnya: menyusun puzzle, lego atau balok kayu.

3. Bermain Pura-Pura (Make-Believe Play) Anak menirukan kegiatan orang yang dijumpainya sehari-hari atau berperan/ memainkan tokoh-tokoh dalam film kartun atau dongeng, yang dimaksud dengan bermain pura-pura dan aplikasinya dalam teori Sarah Smilansky adalah: dramatic play, dimana anak melakukan peran imajinatif atau memerankan tokoh yang dikenalnya melalui film, dongeng, cerita lebih ditekankan pada bermain makro. Contohnya: dokter-dokteran, polisipolisian, atau meniru tukang bakso.

4. Bermain Peraturan (Game with Rule) Dalam kegiatan bermain ini, anak sudah memahami dan bersedia mematuhi peraturan permainan. Aturan permainan pada awalnya dapat dan boleh diubah sesuai kesepakatan orang yang terlibat dalam permainan asalkan tidak menyimpang jauh dari aturan umumnya. Contohnya: bermain ular tangga, bermain tali, monopoli.

5. Bermain peraturan dan olahraga (Games with rules and Sports)

Aturan pada olahraga jauh lebih ketat dan kaku, namun pada tahap ini anak senang melakukan kegiatan ini berulang-ulang dan terpacu untuk mencapai prestasi sebaikbaiknya. Pada tahap ini, bukan hanya rasa senang saja yang menjadi tujuan tetapi ada suatu hasil akhir tertentu seperti ingin menang, memperoleh hasil kerja yang baik. Contohnya: Bermain kucing dan tikus, sepak bola.

Dari ke lima tahapan bermain di atas untuk meningkatkan disiplin anak dengan menggunakan tahapan bermain peraturan, dimana pada tahapan ini anak sudah dapat memahami dan bersedia mematuhi peraturan permainan dan peraturan permainan dapat diubah sesuai kesepakatan orang yang terlibat. Pada tahapan bermain inilah aturan-aturan dalam permainan tersebut dapat diubah dan dibuat sesuai dengan apa yang ingin ditingkatkan (disiplin).

Permainan yang digunakan dalam penelitian ini adalah permainan tradisional. Menurut Cooney 
(dalam Kurniati, 2016: 2), permainan tradisional terbentuk dari aktivitas yang diturunkan dari satu generasi ke generasi berikutnya dan secara berkesinambungan dilakukan oleh banyak orang. Senada dengan pendapat tersebut, Bishop (dalam Mulyadiprana, dkk2017: 185) mengemukakan bahwa permainan tradisional merupakan suatu permainan yang telah dilakukan atau dimainkan oleh anak-anak pada suatu daerah tertentu secara tradisi dan permainan tersebut telah diwariskan dari generasi ke generasi untuk meneruskan tradisi daerah tersebut. Hal ini diperkuat oleh Hapidin, dkk (2016: 204) yang menyatakan bahwa permainan tradisional merupakan bentuk ekspresi dan apresiasi dari tradisi masyarakat dalam menciptakan situasi serta kegiatan yang gembira dan menyenangkan. Melalui permainan tradisional, setiap anggota masyarakat dapat berkumpul, berinteraksi dan berekspresi, baik secara fisik, mental serta emosi. Permainan tradisional merupakan salah satu aset budaya yang mempunyai ciri khas kebudayaan suatu bangsa yang diharapkan bisa membangun karakter anak usia dini.

Dari pendapat para ahli di atas maka dapat disimpulkan bahwa permainan tradisional merupakan salah satu aset budaya secara turun menurun dari genarasi satu ke generasi berikutnya. Selain itu permainan tradisional adalah bentuk ekspresi dan apresiasi dari tradisi masyarakat dalam menciptakan situasi serta kegiatan yang gembira dan menyenangkan, serta memiliki ciri khas kebudayaan bangsa, dan memiliki aturan di setiap permainannya. Sehingga melalui permainan tradisional, anak dapat berkumpul untuk bermain bersama dan akan muncul rasa keakraban, baik secara fisik, mental serta emosi, dengan permainan tradisional inilah karakter kedisiplinan anak usia dini dapat dibangun. Di dalam buku yang dikeluarkan oleh Lembaga direktorat Nilai Budaya (dalam Kurniati, 2016: 3) tertulis bahwa, setiap permainan rakyat tradisional sebenarnya mengandung nilai-nilai yang dapat dimanfaatkan sebagai sarana pendidikan anakanak. Permainan rakyat tradisional selain dapat memupuk kesatuan dan persatuan juga dapat memupuk kerjasama, kebersamaan, kedisiplinan, dan kejujuran.

Dari pendapat di atas maka peneliti memilih satu permainan tradisional yang akan diajarkan kepada anak, yaitu: Permainan Umpet Batu. Adapun gambaran permainan Umpet Batu adalah seperti berikut:

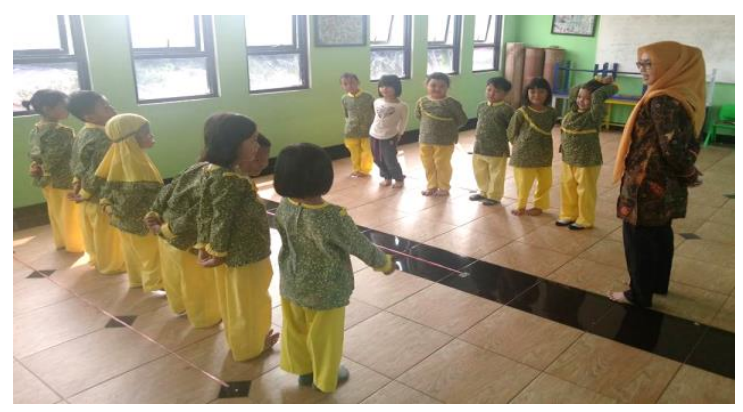

Gambar 1. Permainan Tradisional Umpet Batu

Permainan umpet batu adalah permainan tradisional yang berasal dari wilayah DKI Jakarta. Nama lain dari permainan umpet batu adalah sekolah batu. Permainan ini dimainkan secara berkelompok dengan menggunakan batu kecil sebagai alat untuk disembunyikan, lalu ditebak oleh kelompok lawan. Permainan ini terdiri dari 2 kelompok, tiap kelompok paling sedikit 3 orang. Adapun langkah-langkah cara bermain dalam permainan ini adalah:

1. Membuat 3 garis sejajar

Memberikan 1 buah batu kecil ke masingmasing kelompok

2. Setiap kelompok saling memilih salah satu orang untuk menjadi ketua, anak yang terpilih menjadi ketua melakukan suit untuk menentukan kelompok mana yang harus memulai permainan.

3. Kedua kelompok saling berhadapan dengan menghadap garis tengah, kelompok pemenang meletakkan kedua tangannya ke belakang, posisi tangan menggenggam kecuali ketua kelompok.

4. Ketua kelompok berjalan di belakang anggotanya, tugas ketua kelompok meletakkan batu pada tangan salah satu anggotanya, namun ia harus dapat mengecoh lawan, selanjutnya ketua kelompok bertanya kepada lawan "siapa yang memegang batu?'. Bila tebakan lawan tepat, pemain membenarkan bahwa batu ditangannya, bila tebakan salah pemegang batu maju satu langkah ke garis tengah, jika 
pemain tertebak maka yang memegang batu mundur satu langkah dan tidak boleh bermain lagi.

5. Permainan dinyatakan selesai apabila salah satu anggota kelompok sudah sampai di garis tengah dan dinyatakan kelompok tersebut sebagai pemenang.

Berdasarkan uraian di atas, maka tujuan penelitian ini adalah untuk meningkatkan disiplin anak kelompok B melalui permainan tradisional.

\section{METODE PENELITIAN}

Penelitian ini menggunakan jenis penelitian tindakan kelas yang dilaksanakan selama 2 siklus dalam 6 kali pertemuan dimana tiap-tiap siklus terdiri dari 3 kali tatap muka. Penelitian ini akan dilaksanakan di TK Al Kautsar, Jakarta Timur. Kegiatan penelitian dilakukan pada semester I dimulai dari bulan Juli-Agustus 2018. Subjek penelitian ini adalah murid kelompok B1 (Bunga Anggrek) di TK Al Kautsar Jakarta Timur, yang berusia 5-6 tahun dengan jumlah 24 anak yang terdiri dari 9 anak laki-laki dan 15 anak perempuan.

Pada penelitian ini peneliti merancang tindakan, melaksanakan tindakan, mengobservasi, merefleksi tindakan, dan menyusun laporan penelitian, sedangkan guru bertugas membantu peneliti dalam merancang tindakan, mengobservasi, serta refleksi yang bertujuan untuk meningkatkan disiplin anak dalam melaksanakan pembelajaran. Hal tersebut sesuai dengan apa yang dikatakan Asmani (2011: 144) bahwa rancangan prosedur penelitian yang harus dilakukan dalam penelitian tindakan kelas adalah membuat perencanaan (planning), pelaksanaan tindakan (acting), pengamatan/ observasi (observating), refleksi (reflecting).

Adapun desain penelitian yang digunakan dalam penelitian ini yaitu model penelitian tindakan Kemmis dan Mc Taggart.

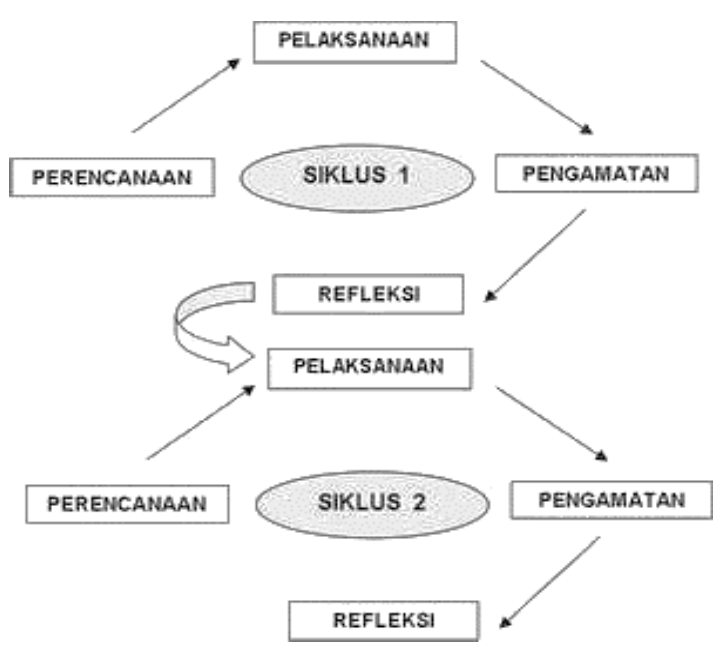

Gambar 2. Rancangan Penelitian Kemmis dan Mc Taggart

Teknik pengumpulan data menggunakan observasi dan dokumentasi. Observasi dilakukan dengan menggunakan lembar observasi yang telah dipersiapkan dalam bentuk check list. Adapun data yang akan diambil adalah peningkatan disiplin anak melalui permainan tradisional. Sementara dokumentasi yang dikumpulkan berupa foto alat yang digunakan dalam penelitian, serta foto dan video pelaksanaan kegiatan.

Teknik analisis data menggunakan analisis deskripsi kualitatif dan kuantitatif, yaitu suatu metode penelitian yang bersifat menggambarkan kenyataan atau fakta sesuai dengan data yang diperoleh dengan tujuan untuk mengetahui hasil belajar yang dicapai siswa juga untuk mengetahui respon siswa terhadap kegiatan serta aktivitas siswa selama proses belajar mengajar berlangsung menurut (Aqib, 2009: 40). Adapun rumus yang digunakan untuk menghitung tingkat disiplin anak, sebagai berikut:

$$
\mathrm{P}=\frac{F}{N} \times 100 \%
$$

Keterangan:

$\mathrm{P}=$ Presentase

$\mathrm{F}=$ Jumlah skor yang diperoleh siswa

$\mathrm{N}=$ Jumlah seluruh siswa dalam kelas (Marliza, 2012: 4-5) 
Indikator keberhasilan penentuan kriteria tersebut $75 \%$ sesuai dengan kriteria dari Widyoko (2015: 242) yang dapat dilihat pada tabel berikut:

Tabel 1. Kriteria Keberhasilan

\begin{tabular}{cc}
\hline $\begin{array}{c}\text { Persentase } \\
\text { Ketuntasan }\end{array}$ & Klasifikasi \\
\hline$>80$ & Sangat Baik \\
\hline$>60-80$ & Baik \\
\hline$>40-60$ & Cukup \\
\hline$>20-40$ & Kurang \\
\hline$\leq 20$ & Sangat Kurang \\
\hline
\end{tabular}

\section{HASIL DAN PEMBAHASAN}

Tabel 2. Rekapitulasi Disiplin Melalui Permainan Tradisional pada Siklus I

\begin{tabular}{|c|c|c|c|c|c|c|}
\hline \multirow{2}{*}{ Siklus I } & \multicolumn{3}{|c|}{$\begin{array}{c}\text { Taat terhadap aturan } \\
\text { permainan }\end{array}$} & \multicolumn{3}{c|}{ Mengatur diri sendiri } \\
\cline { 2 - 7 } & \multicolumn{3}{|c|}{ Skor } & \multicolumn{3}{c|}{ Skor } \\
\cline { 2 - 7 } & 1 & 2 & 3 & 1 & 2 & 3 \\
\hline Pertemuan 1 & 9 & 10 & 5 & 9 & 10 & 5 \\
\hline Presentase (\%) & $37,5 \%$ & $41,6 \%$ & $20,8 \%$ & $37,5 \%$ & $41,6 \%$ & $20,8 \%$ \\
\hline Pertemuan 2 & 9 & 8 & 6 & 9 & 8 & 6 \\
\hline Presentase (\%) & $39,1 \%$ & $34,7 \%$ & $26,0 \%$ & $39,1 \%$ & $34,7 \%$ & $26,0 \%$ \\
\hline Pertemuan 3 & 6 & 9 & 7 & 6 & 9 & 7 \\
\hline Presentase (\%) & $27,2 \%$ & $40,9 \%$ & $31,8 \%$ & $27,2 \%$ & $40,9 \%$ & $31,8 \%$ \\
\hline $\begin{array}{c}\text { Rata-rata } \\
\text { ketercapaian }\end{array}$ & $34,6 \%$ & $39,0 \%$ & $26,2 \%$ & $34,6 \%$ & $39,0 \%$ & $26,2 \%$ \\
\hline
\end{tabular}

Tabel 2. Rekapitulasi Disiplin Melalui Permainan Tradisional pada Siklus II

\begin{tabular}{|c|c|c|c|c|c|c|}
\hline \multirow{2}{*}{ Siklus II } & \multicolumn{3}{|c|}{$\begin{array}{c}\text { Taat terhadap aturan } \\
\text { permainan }\end{array}$} & \multicolumn{3}{c|}{ Mengatur diri sendiri } \\
\cline { 2 - 7 } & \multicolumn{3}{|c|}{ Skor } & \multicolumn{3}{c|}{ Skor } \\
\cline { 2 - 7 } & 1 & 2 & 3 & 1 & 2 & 3 \\
\hline Pertemuan 1 & 4 & 7 & 11 & 4 & 7 & 11 \\
\hline Presentase (\%) & $18,1 \%$ & $29,1 \%$ & $50 \%$ & $18,1 \%$ & $29,1 \%$ & $50 \%$ \\
\hline Pertemuan 2 & 1 & 7 & 14 & 1 & 7 & 14 \\
\hline Presentase (\%) & $4,5 \%$ & $31,8 \%$ & $63,6 \%$ & $4,5 \%$ & $31,8 \%$ & $63,6 \%$ \\
\hline Pertemuan 3 & 1 & 4 & 17 & 1 & 4 & 17 \\
\hline Presentase (\%) & $4,5 \%$ & $18,1 \%$ & $77,2 \%$ & $4,5 \%$ & $18,1 \%$ & $77,2 \%$ \\
\hline $\begin{array}{c}\text { Rata- rata } \\
\text { ketercapaian }\end{array}$ & $9,0 \%$ & $26,3 \%$ & $63,6 \%$ & $9,0 \%$ & $26,3 \%$ & $63,6 \%$ \\
\hline
\end{tabular}

Tabel 3 Persentase Peningkatan Per-Siklus

\begin{tabular}{|c|c|c|c|c|}
\hline $\mathrm{N}_{0}$ & Indikator Penilaian & $\begin{array}{c}\text { Hasil Siklus } \\
\text { I }\end{array}$ & $\begin{array}{c}\text { Hasil Siklus } \\
\text { II }\end{array}$ & $\begin{array}{c}\text { Peningkatan } \\
(\%)\end{array}$ \\
\hline \multirow[t]{2}{*}{1.} & Taat Terhadap Aturan & 7 & 17 & \multirow{2}{*}{$45,4 \%$} \\
\hline & Permainan & $31,8 \%$ & $77,2 \%$ & \\
\hline \multirow[t]{2}{*}{2.} & Mengatur Diri Sendiri & 7 & 17 & \multirow{2}{*}{$45,4 \%$} \\
\hline & & $31,8 \%$ & $77,2 \%$ & \\
\hline
\end{tabular}

\section{Peningkatan Per Siklus}

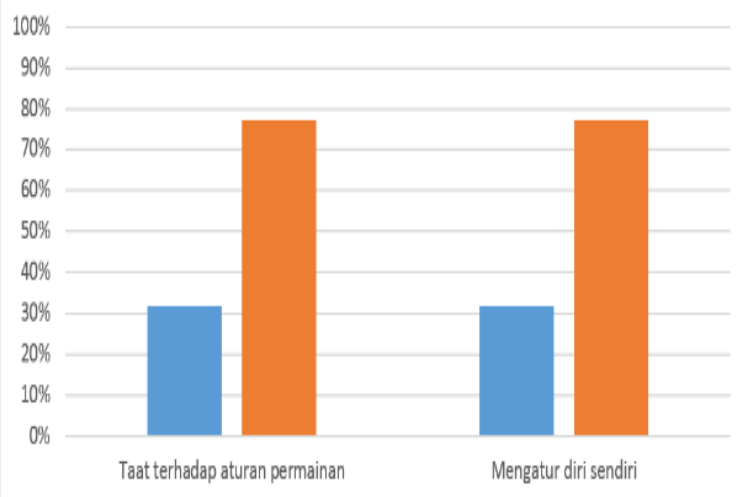

Gambar 5 Grafik Persentase Peningkatan PerSiklus

Ketercapaian perkembangan dalam disiplin ini dilakukan dengan menggunakan metode bermain permainan tradisional umpet batu. Keberhasilan ini dapat terlihat ketika anak mampu melakukan kegiatan permainan sesuai dengan langkah-langkah permainan seperti pada saat guru memilih anak yang dapat duduk rapi dan dapat menjawab pertanyaan terlebih dahulu untuk dapat menempati nomer urut yang guru perintahkan. hal inilah yang membuat anak mau untuk duduk rapi. karena dengan duduk rapi anak dapat dipilih untuk menjawab pertanyaan dari guru dan dapat menempati nomer urut yang guru perintahkan. dari sinilah terlihat anak dapat bertanggung jawab atas perilakunya untuk kebaikan diri sendiri.

Kemudian pada saat berbaris. dalam permainan ini anak diminta untuk berbaris dengan rapi sesuai dengan nomor urutnya. Anak dapat maju satu langkah menuju kotak berikutnya ketika anak memegang batu, tetapi ia tidak tertebak 
oleh lawannya. Kemudian anak dapat mundur satu langkah ke kotak yang berada di belakangnya ketika ia memegang batu dan ia tertebak oleh kelompok lawan. Dari sinilah dapat terlihat anak sudah dapat mengetahui akan haknya dalam permainan ini. Pada saat guru sudah memerintahkan anak untuk menempati nomer yang telah guru pilihkan untuk anak tempati. anak tersebut langsung menempati kotak nomer tersebut tanpa bermalas-malasan terlebih dahulu dan tanpa memilih-milih nomor lain untuk ditempati. kemudian pada saat anak dapat berbaris dengan rapi sambil meletakkan tangannya ke belakang tanpa diingatkan oleh guru. dalam hal ini dapat terlihat bahwa anak sudah dapat mengatur dirinya sendiri ketika ia sudah mengetahui cara bermain dan mengetahui aturan dalam setiap tahap permainan.

Adanya aturan-aturan di setiap langkah permainan ini anak dapat terlatih untuk mentaati segala jenis aturan-aturan yang berlaku. dan dari sinilah anak dapat mengetahui akan haknya. dapat mematuhi aturan dalam kegiatan permainan kemudian dapat mengatur diri sendiri serta dapat bertanggung jawab terhadap apa yang ia lakukan.

Sesuai yang telah dijelaskan dalam Permendikbud Nomor 137 (2014: 28) Tentang Standar Pendidikan Anak Usia Dini dalam Standar Pencapaian Perkembangan Anak. kemampuan pada anak kelompok B (usia 5-6 tahun) berada dalam kemampuan rasa tanggung jawab untuk diri sendiri dan orang lain. penerapan disiplin melalui bermain ini membuat anak mengetahui akan haknya. mentaati aturan kelas (kegiatan. aturan). mengatur diri sendiri. dan dapat bertanggung jawab atas perilakunya untuk kebaikan diri sendiri. Hal ini juga terdapat pada kurikulum 2013 (2014: 12) indikator pencapaian perkembangan anak usia dini dari 0-6 tahun yang terdapat pada KD 2.6. Memiliki perilaku yang mencerminkan sikap taat terhadap aturan sehari-hari untuk melatih kedisiplinan dan KD 2.7.

Memiliki perilaku yang mencerminkan sikap sabar (mau menunggu giliran. mau mendengar ketika orang lain berbicara) untuk melatih kedisiplinan. Kegiatan yang menunjukkan perilaku disiplin serta rasa tanggung jawab untuk diri sendiri dan orang lain serta sikap sabar adalah dengan taat terhadap aturan permainan dan dapat mengatur diri sendiri.

Adapun hasil kemampuan disiplin pada siklus I. rata-rata ketercapaian dalam taat terhadap aturan permainan yaitu sebesar $31.8 \%$. dan mengatur diri sendiri yaitu sebesar $31.8 \%$. Sedangkan pada siklus II. rata-rata ketercapaian dalam taat terhadap aturan permainan yaitu sebesar $77.2 \%$ dan mengatur diri sendiri yaitu sebesar $77.2 \%$. Dari siklus I dan II masingmasing anak pada tiap indikator terdapat peningkatan yang telah mencapai indikator keberhasilan. nilai rata-rata ketercapaian pada siklus I dan II dalam ketercapaian taat terhadap aturan permainannya itu sebesar $45.4 \%$ dan nilai rata-rata dalam ketercapaian mengatur diri sendiri sebesar $45.4 \%$.

Hal ini senada dengan pendapat Hidayati (2016: 156) disiplin adalah sikap ketaatan dan kepatuhan terhadap peraturan dan norma yang berlaku. Disiplin merupakan salah satu sikap yang menjadi kunci keberhasilan dalam aktivitas peserta didik. Selain itu terdapat ciriciri keberhasilan disiplin pada penelitian ini yaitu. ketika anak sudah mampu patuh terhadap aturan. tidak melanggar peraturan yang berlaku. dan tidak membohong. Disiplin dalam permainan ini mengajarkan anak tentang disiplin waktu. contohnya pada saat bermain anak diberikan giliran $1 \mathrm{x}$ untuk menebak letak keberadaan batu. kemudian guru memberi waktu kepada anak untuk dapat memutuskan pilihannya (menebak). Kemudian disiplin dalam bertata krama. contohnya anak mau menyebut nomer urut lawan tanpa berteriak. dan tidak menyalahkan temannya ketika temannya tertebak memegang batu.

Sebelum permainan ini dimulai guru menjelaskan dan mencontohkan secara langsung kepada anak bagaimana cara bermaian permainan umpet batu yang benar. pada saat meberikan contoh permainan kepada anak guru tidak lupa menjelaskan aturan-aturan permainan yang harus anak patuhi. Dalam memberikan aturan kepada anak guru harus konsisten dalam menjalankan aturan yang telah dibuat. tujuannya agar disiplin dalam diri anak dapat terbentuk dengan baik.

Permainan ini berada pada tahap permainan bermain Peraturan (Game with Rule) dimana dalam kegiatan bermain ini. anak sudah dapat 
memahami dan bersedia mematuhi peraturan permainan. Melalui permainan inilah anak dapat mengembangkan disiplin tanpa adanya paksaan. dan dilakukan dengan cara yang menyenangkan. Selain itu kegiatan permainan tradisional ini mengandung banyak manfaat bagi diri anak dan dapat membantu meningkatkan aspek perkembangan anak seperti sosial-emosional. anak dilatih untuk dapat bersabar menunggu giliran mendapatkan batu dan bersabar untuk mendapatkan giliran menebak nomer pemegang batu. Selanjutnya aspek motorik. dalam kegiatan permainan ini anak melakukan gerakan seperti melangkah maju. mundur. dan menggenggam. Kemudian pada aspek bahasa. dalam permainan ini anak harus memberanikan diri untuk menyebutkan nomer pilihannya untuk ditebak.

Salah satu faktor yang dapat mendukung meningkatnya disiplin pada anak adalah adanya reward. Anak akan merasa senang setelah apa yang dilakukan olehnya mendapatkan apresiasi atau penghargaan terhadap dirinya. Hal tersebut akan memunculkan semangat-semangat baru di dalam diri anak. sehingga akan muncul hal-hal positif seperti membiasakan diri untuk hidup teratur sesuai aturan berlaku di rumah maupun di sekolah.

\section{SIMPULAN DAN SARAN}

Berdasarkan hasil data yang diperoleh darisiklus I dan siklus II dapat disimpulkan bahwa terdapat peningkatan disiplin pada anak kelompok B1 melalui permainan tradisional umpet batu di TK Al Kautsar. Jakarta Timur.

Terjadinya peningkatan disiplin dikarenakan adanya: 1). media pembelajaran seperti batu warna warni yang dapat menarik minat anak untuk bermain; 2). adanya penguasaan kelas yang baik sehingga membuat anak mau memperhatikan dan memahami aturan di setiap langkah permainan; 3). Adanya jarak dan waktu pada tiap-tiap garis awal agar anak mudah mencapai garis tengah dan tidak melewati batas waktu dalam permainan; dan 5). Adanya reward berupa stiker bintang. yang ditujukan untuk memberi motivasi dan antusiasme dalam melakukan kegiatan permainan tradisional umpet batu.

Berdasarkan hasil penelitian tersebut. saran yang dapat diberikan adalah: pertama. permainan tradisional umpet batu dapat dijadikan referensi guru untuk melatih disiplin anak karena permainan umpet batu memiliki aturan dalam permainan tersendiri; kedua. menjadikan metode bermain sebagai salah satu metode pembelajaran. hal ini bertujuan agar anak tidak mudah bosen dalam mengikuti pembelajaran di kelas; dan ketiga. sebaiknya guru memberikan reward seperti stiker bintang, senyuman, sebagai penghargaan keberhasilan yang dicapai anak sekaligus untuk meningkatkan kecepat tanggapan anak serta antusiasme dalam melakukan kegiatan pembelajaran dan permainan.

Adapun saran bagi kepala sekolah adalah agar kepala sekolah menghimbau guru untuk melakukan kegiatan permainan tradisional minimal seminggu sekali yang di setiap langkahnya terdapat aturan-aturan permainan.

\section{DAFTAR PUSTAKA}

Aqib, Z. (2009). Penelitian tindakan kelas untuk guru. SD. SLB. TK. Bandung: CV YramaWidya.

Asmani, M., Dkk. (2011). Tips pintar PTK: Penelitian Tindakan Kelas. Yogyakarta: Laksana.

Aulina, N., Choirun. (2013). Penanaman disiplin pada anak usia dini. Pedagogia. Vol. 2. No.1. Hal. 36-49.

Hidayati, A. (2016). Desain kurikulum pendidikan karakter. Jakarta: Kencana.

Kertamuda, A.M (2015). Golden age. Jakarta: PT. Elex Media Komputindo.

Kurniati, E. (2016). Permainan tradisional dan perannya dalam mengembangkan keterampilan sosial anak. Jakarta: Prenada Media Group.

Marliza. (2012). Peningkatan kemampuan motorik halus anak melalui permainan melukis dengan kuas taman kanak-kanak pasaman barat. Jurnal Pesona PAUD Vol. 1. No. 1.

Mufidah, U. (2012). Efektivitas pemberian reward melalui metode token ekonomi untuk meningkatkan kedisiplinan anak usia dini. Journal of Early Childhood Education Papers.

Mulyadiprana, A., dkk. (2017). Permainan tradisional Kaulinan Barudak untuk mengembangkan kemampuan mengelola emosi diri sendiri anak usia dini. Jurnal PAUD Agapedia. Vol.1. No.2. Hal. 81-189. 
Mulyani, N. (2016). Super asyik permainan tradisional anak Indonesia. Yogyakarta: Diva Press.

Musfiroh,T. (2008). Cerdas melalui bermain. Jakarta: Grasindo.

Peraturan Menteri Pendidikan dan Kebudayaan Republik Indonesia Nomor 146 Tahun2014 tentang kurikulum 2013 pendidikan anak usia dini.

Peraturan Menteri Pendidikan dan Kebudayaan Republik Indonesia Nomor 137 Tahun2014 tentang kurikulum 2013 pendidikan anak usia dini. 